\section{Occupational exposure to acid mists and periodontal attachment loss}

\author{
Exposição ocupacional a névoas ácidas e perda de \\ inserção periodontal
}

\section{${ }^{1}$ Instituto de Saúde Coletiva, Universidade Federal da Bahia, Salvador, Brasil. 2 Escola de Odontologia, Universidade Federal da Bahia, Salvador, Brasil. ${ }^{3}$ Departamento de Saúde, Universidade Estadual de Feira de Santana, Feira de Santana, Brasil. \\ Correspondence T. F. Almeida Instituto de Saúde Coletiva Universidade Federal da Bahia. \\ Rua João Bião de Cerqueira 251, apto. 702A, Salvador, BA 41830-580, Brasil. tatifrederico@hotmail.com}

\section{Abstract}

This study investigated the hypotheses that occupational exposure to acid mists is positively associated with periodontal disease, assessed by periodontal attachment loss. The study sample included 530 male workers at a metal processing factory. Data were obtained from interviews and oral examinations. Periodontal attachment loss was defined as $\geq 4 \mathrm{~mm}$ at probing, in at least one tooth. A job exposure matrix was utilized for exposure evaluation. Exposure to acid mists was positively associated with periodontal attachment loss $\geq 4 \mathrm{~mm}$ at any time (prevalence ratio, $\left.P R_{\text {adjusted }}=2.17\right)$, past $\left(P R_{\text {adjusted }}=2.11\right)$, and over 6 years of exposure $\left(P R_{\text {adjusted }}=1.77\right)$, independently of age, alcohol consumption, and smoking, and these results were limited to workers who did not use dental floss. Exposure to acid mists is a potential risk factor for periodontal attachment loss, and further studies are needed, using longitudinal designs and more accurate exposure measures.

Periodontal Attachment Loss; Inorganic Acids; Periodontal Diseases; Occupational Exposure
Tatiana F. de Almeida 1 Maria Isabel P. Vianna 2 Vilma S. Santana 1 Isaac S. Gomes Filho 3

\section{Introduction}

The oral cavity is vulnerable to external agents, and some occupational exposures are associated with oral changes in both hard and soft tissues. Occupational exposure to sulfuric acid mists has been described in association with dental erosion and ulcerative mucosal lesions 1,2,3,4, explained by the high irritant and corrosive acid effects that damage the enamel structure, cause inflammatory and immune reactions, and reduce the salivary $\mathrm{pH}$ that can also compromise resistance to infections in the oral cavity 5 . Less studied is the association between inorganic acid exposures and periodontal lesions. A few studies have reported a positive association between occupational exposures to strong acids and periodontal pockets or gingival bleeding 6,7 and an increased prevalence of gingival bleeding among exposed workers $7,8,9$. In a previous study conducted in the same factory targeted in the current investigation, no association was found between acid mists or acid gases and high changes in periodontal scores, a summary indicator of overall periodontal health 10 .

Periodontal disease comprises a group of chronic inflammatory diseases that affects the supporting tissues of the teeth and is associated with gingival bleeding, periodontal pockets, redness, and periodontal attachment loss (PAL) 11 . The destructive forms of these diseases are characterized by loss of tooth epithelial attachment 
to gingival connective tissues and resorption of the alveolar bone that provides physical support to the dental structure ${ }^{12}$. PAL corresponds to the distance from the cementum-enamel junction to the gingival sulcus or periodontal pocket 13 . PAL has been recognized as a relevant late stage of periodontal disease, because it is an important predictor of destructive forms of this frequently irreversible condition 14,15. Exogenous agents like nicotine, alcohol 16, and lead 2 may cause or contribute to the occurrence of severe forms of periodontal destruction, such as PAL. No studies addressing the association between exposure to acid mists and PAL. The purpose of this study was thus to examine the hypothesis that occupational exposure to acid mists is a potential risk factor for PAL.

\section{Methods}

This was a cross-sectional study of all active workers in a metal processing plant in Brazil, where acid agents, particularly sulfuric acid, are used extensively in several stages of the production process. Since 1999, an oral health promotion program has been under development by a nationwide institution that provides subsidized occupational health services to the manufacturing industry in Brazil. The program's strategy is based on yearly visits to an oral health care facility, located in the plant, during which the workers are individually interviewed to obtain sociodemographic, occupational, life-style, and clinical history. They also have a complete oral exam including a full investigation of periodontal status. When recommended, dental treatment and/or participation in a health education program are made available. The study population comprises all active male workers and trainees who volunteered to participate in this oral health promotion program and had at least one oral exam during the study period, from 2000 to 2003, when an appropriate investigation of periodontal status was performed. Before this period, periodontal status had been evaluated using the community periodontal index methodology 17 , which recommends a partial and hierarchical exam. Because some workers did not attend all scheduled visits, only the most recent exam was considered. Women were excluded because they represent a small proportion of workers, and most were not exposed to the acid substances under investigation. Edentulous individuals and wearers of fixed orthodontic appliances were also excluded.

Dentists in charge of the clinical examinations were trained to perform standardized procedures according to the community periodontal index and attachment loss index proposed in the World Health Organization guidelines 17 . The oral health program protocol states that periodontal assessment should be conducted by examining every surface of each tooth using a CPI probe 17 . Therefore, distinctly from the traditional evaluation procedure that recommends examining some index teeth17, all tooth surfaces were examined. Additionally, all periodontal conditions according the community periodontal index and attachment loss index criteria are recorded, and not only the more severe alterations as proposed by WHO 17. PAL was defined as periodontal attachment level $34 \mathrm{~mm}$ at probing in at least one site of one tooth, according to Kingman \& Albandar 13 who considered the presence of periodontal disease as the dependent variable. Exposure assessment was conducted using a job exposure matrix with job titles on one axis and inorganic acids on the other. Industrial hygienists from the factory recorded whether exposure was likely to occur in each corresponding job title. In this study, acid mists comprise a mixture of inorganic acids, specifically sulfuric acid, chlorhydric acid, electrolytic solution of sulfuric acid and acid "water" that expresses diluted sulfuric acid. Based on data from each worker's occupational history obtained from the plant log, the time spent on each job position identified as "exposed" was summed to obtain a total exposure time to acid mists. Exposure-related data were analyzed using three different variables: history of exposure (ever and never exposed); experience of exposure (past, currently, and never exposed); duration of exposure ( $>6$ years, $\leq 6$ years, and never exposed). Covariates were: sociodemographic (age in years and education: college versus less than college); life style (smoking: non-smoker versus smoker/ ex-smoker), alcohol consumption (nondrinker versus frequent/occasional drinker), and oral health habits, assessed by the frequency of dental flossing and dental visits, both coded as frequent, rare/never. Oral breathing was assessed by asking workers whether they "frequently breath through the mouth" (yes/no).

\section{Statistical methods}

Unconditional logistic regression was used to estimate prevalence ratios for the association between acid mist exposure and periodontal attachment loss. Statistical inference was based on $95 \%$ confidence intervals estimated with the Delta method 18. Modeling was conducted using backward procedures, starting with a complete equation with all potential confounders, effect modifiers, and their corresponding product terms. Confounders were covariates that 
changed the estimated association between acid mist exposure and PAL by at least $20 \%$. Findings from previous studies and the theoretical framework were also used to assess confounding. Effect modifiers were identified using the maximum likelihood ratio test. Linearity was examined for the variables under analysis and regression diagnosis performed with influence analysis. Data entry used Epi Info 6.03 (Centers for Disease Control and Prevention, Atlanta, USA) and statistical analysis used SAS 8.01 (SAS Inst., Cary, USA). The study protocol was reviewed and approved by the Institutional Review Board of the Instituto de Saúde Coletiva, Universidade Federal da Bahia [Institute of Collective Health, Federal University in Bahia]. Study participants signed an informed consent form and received information about their oral health status. Treatment was provided when indicated at no charge to workers.

\section{Results}

There were a total of 731 workers in the plant at the beginning of the oral health program in 1999, but only 598 (82\%) had at least one oral exam during the defined study period. Women (54; 8.9\%), edentulous individuals, and wearers of fixed orthodontic appliances $(16 ; 2.7 \%)$ were excluded, leaving 530 workers for analysis. Table 1 shows that workers who had ever been exposed to acid mists were younger and had less schooling than the non-exposed. Frequent flossing, dental visits, and alcohol consumption were more commonly reported by those who had ever been exposed, but oral breathing was more frequent in the nonexposed group. No difference was found in smoking according to exposure status (Table 1).

Exposure to acid mists was common in the study population. A total of 216 workers $(40.8 \%)$ had ever been exposed, 163 (30.8\%) were currently exposed, and considering the cumulative exposure time, 123 (23.2\%) had over 6 years of exposure (Table 2). Prevalence of periodontal attachment loss was estimated as $25.3 \%$ (134/530) in the total sample. Of the workers who had ever been exposed to acid mists, $26.4 \%$ showed PAL, similar to the rate in the non-exposed group (24.5\%), a non-statistically significant difference. No differences were found for PAL prevalence according to all other exposure-related variables (Table 2).

Based on unconditional logistic regression, frequency of flossing was an effect modifier of the association between history of exposure to acid mists and PAL (maximum likelihood ratio test, $\chi^{2}=4.99,1$ degree of freedom, $\mathrm{df}, \mathrm{p}=0.025$ ), therefore all results are presented separately for each category of this covariate. Age was identified as a confounding covariate. Final prevalence ratios were also adjusted for alcohol consumption and smoking based on theoretical considerations, since no empirical evidence of their confounding effect was observed (Table 3). In the group of workers who did not report frequent flossing, individuals who had ever been exposed to acid mists were more likely to have PAL $\left(\mathrm{PR}_{\text {adjusted }}=\right.$ 2.17; 95\%CI: $1.26-3.76$ ) as compared to non-exposed workers, after adjusting for age, alcohol consumption, and smoking. Similarly, workers with past exposure to acid mists had a higher prevalence of PAL $\left(\mathrm{PR}_{\text {adjusted }}=2.11 ; 95 \% \mathrm{CI}\right.$ : 1.163.86) than those who had never been exposed. More than 6 years of exposure to acid mists was also positively associated with PAL for adjusted $\left(\mathrm{PR}_{\text {adjusted }}=1.77 ; 95 \% \mathrm{CI}: 1.04-3.00\right)$ and crude $\left(\mathrm{PR}_{\text {crude }}=1.62 ; 95 \% \mathrm{CI}: 1.02-2.55\right)$ estimates. In contrast, in the group of non-frequent dental floss users, no statistically significant differences were found (Table 3).

\section{Discussion}

Results from this study suggest that individuals exposed to inorganic acids like acid mists composed of mixtures of sulfuric and chlorhydric acid have an increased prevalence of PAL, a common periodontal health problem, but this association was limited to the group that reported non-frequent use of dental floss. Although PAL had not been investigated as a potential effect of exposure to acid mists, these results are consistent with other findings indicating a positive association between occupational exposure to acid products and symptoms of periodontal disease, such as gingival bleeding 7,8,9 and periodontal pockets $\geq 4 \mathrm{~mm} 6,7$. However, no association was found between bone loss, another periodontal disease sign, and exposure to electrolytic solutions 7. None of these studies considered confounders or effect modifiers in the analysis. A previous study conducted in this same factory tested the hypothesis that exposure to acid mists was associated with periodontal changes using a composite indicator, the community periodontal index of treatment needs (CPITN), and no statistically significant differences were found, even considering several appropriate covariates in the analysis 10 .

Interestingly, past exposure to acid mists and exposure of greater than 6 years were positively associated with PAL in the study population, which supports existing knowledge that this is a chronic although non-continuous and cumulative destructive periodontal disease 16 . The find- 
Characteristics of the study population according to history of occupational acid mist exposure $(n=530)$, Brazil.

\begin{tabular}{|c|c|c|c|c|}
\hline \multirow[t]{3}{*}{ Variables } & \multicolumn{4}{|c|}{ History of exposure } \\
\hline & \multicolumn{2}{|c|}{ Ever exposed } & \multicolumn{2}{|c|}{ Never exposed } \\
\hline & $n=216$ & $\%$ & $n=314$ & $\%$ \\
\hline \multicolumn{5}{|l|}{ Age in years } \\
\hline $21-41$ & 128 & 59.3 & 144 & 45.9 \\
\hline $42-67$ & 88 & 40.7 & 170 & 54.1 \\
\hline \multicolumn{5}{|l|}{ Schooling * } \\
\hline Less than college & 175 & 82.9 & 222 & 71.4 \\
\hline College & 36 & 17.1 & 89 & 28.6 \\
\hline \multicolumn{5}{|l|}{ Oral breathing * } \\
\hline Yes & 23 & 10.7 & 44 & 14.2 \\
\hline No & 193 & 89.3 & 267 & 85.8 \\
\hline \multicolumn{5}{|l|}{ Frequency of dental visits * } \\
\hline Frequent & 162 & 75.0 & 245 & 78.5 \\
\hline Rarely/Never & 54 & 25.0 & 67 & 21.5 \\
\hline \multicolumn{5}{|l|}{ Frequency of dental floss use * } \\
\hline Frequent & 138 & 64.8 & 198 & 63.5 \\
\hline Rarely/Never & 75 & 35.2 & 114 & 36.5 \\
\hline \multicolumn{5}{|l|}{ Smoking } \\
\hline Smoker/Ex-smoker & 70 & 32.4 & 102 & 32.5 \\
\hline Non-smoker & 146 & 67.6 & 212 & 67.5 \\
\hline \multicolumn{5}{|l|}{ Alcohol consumption } \\
\hline Drinker (occasional/frequent) & 184 & 85.2 & 253 & 80.6 \\
\hline Nondrinker & 32 & 14.8 & 61 & 19.4 \\
\hline
\end{tabular}

* Some totals differ because of missing values for schooling (eight), oral breathing (three), frequency of dental visits (two), and frequency of dental floss use (five).

Table 2

Crude and adjusted prevalence ratios (PR) and their Mantel-Haenszel $95 \%$ confidence intervals (95\%Cl) for the association between acid mist exposure and periodontal attachment loss ( $\geq 4 \mathrm{~mm}$ in at least one tooth).

\begin{tabular}{|c|c|c|c|c|}
\hline Variables of acid mist exposure & $\mathrm{n}$ & Prevalence percentage & $\mathrm{PR}_{\text {crude }} *(95 \% \mathrm{Cl})$ & $\mathrm{PR}_{\text {adjusted }} * \star(95 \% \mathrm{Cl})$ \\
\hline \multicolumn{5}{|l|}{ History of exposure } \\
\hline Never exposed & 314 & 24.52 & 1.00 & - \\
\hline Ever exposed & 216 & 26.39 & $1.08(0.80-1.45)$ & $1.20(0.90-1.60)$ \\
\hline \multicolumn{5}{|l|}{ Experience of exposure } \\
\hline Never & 314 & 24.52 & 1.00 & - \\
\hline Current & 163 & 27.61 & $1.13(0.82-1.54)$ & $1.23(0.90-1.67)$ \\
\hline Past & 53 & 22.64 & $0.92(0.54-1.58)$ & 1.07 (0.64-1.79) \\
\hline \multicolumn{5}{|l|}{ Duration of exposure } \\
\hline Never & 314 & 24.52 & 1.00 & - \\
\hline$\geq 6$ years & 93 & 20.43 & $0.83(0.53-1.30)$ & $1.05(0.69-1.60)$ \\
\hline$>6$ years & 123 & 30.89 & $1.26(0.91-1.75)$ & $1.30(0.94-1.79)$ \\
\hline
\end{tabular}

* Crude prevalence ratio;

** Age-adjusted prevalence ratio. 
Crude and adjusted prevalence ratios (PR) and 95\% confidence intervals (Delta method; $95 \% \mathrm{Cl}$ ) for the association between acid mist exposure and periodontal attachment loss according to frequency of dental floss use.

\begin{tabular}{|c|c|c|c|c|}
\hline \multirow[t]{3}{*}{ Models } & \multicolumn{4}{|c|}{ Frequency of dental floss use $(n=525)$ * } \\
\hline & \multicolumn{2}{|c|}{ Rare/Never $(n=189)$} & \multicolumn{2}{|c|}{ Frequent $(n=336)$} \\
\hline & PR & $95 \% \mathrm{Cl}$ & PR & $95 \% \mathrm{Cl}$ \\
\hline \multicolumn{5}{|l|}{ History of exposure } \\
\hline \multicolumn{5}{|l|}{ Model 1} \\
\hline Ever exposed & 1.47 & $0.94-2.28$ & 0.90 & $0.60-1.34$ \\
\hline \multicolumn{5}{|l|}{ Model 2} \\
\hline Ever exposed (adjusted for age) ** & 2.17 & $1.26-3.74$ & 1.08 & $0.70-2.28$ \\
\hline \multicolumn{5}{|l|}{ Model 3} \\
\hline \multicolumn{5}{|c|}{ Ever exposed (adjusted for age ${ }^{\star \star}$, alcohol } \\
\hline consumption, smoking) & 2.17 & $1.26-3.76$ & 1.11 & $0.72-1.70$ \\
\hline \multicolumn{5}{|l|}{ 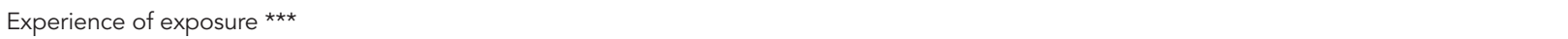 } \\
\hline \multicolumn{5}{|l|}{ Model 1} \\
\hline Current & 1.28 & $0.81-2.04$ & 1.12 & $0.74-1.68$ \\
\hline Past & 1.41 & $0.80-2.49$ & 0.41 & $0.14-1.22$ \\
\hline \multicolumn{5}{|l|}{ Model 2 (adjusted for age) ** } \\
\hline Current & 1.52 & $0.89-2.59$ & 1.28 & $0.84-1.97$ \\
\hline Past & 2.12 & $1.17-3.85$ & 0.50 & $0.17-1.49$ \\
\hline \multirow{2}{*}{\multicolumn{5}{|c|}{$\begin{array}{l}\text { Model } 3 \text { (adjusted for age }{ }^{* *} \text {, alcohol } \\
\text { consumption, smoking) }\end{array}$}} \\
\hline & & & & \\
\hline Current & 1.53 & $0.90-2.61$ & 1.31 & $0.86-2.03$ \\
\hline Past & 2.11 & $1.16-3.86$ & 0.51 & $0.17-1.52$ \\
\hline \multicolumn{5}{|l|}{ Duration of exposure $* \star \star$} \\
\hline \multicolumn{5}{|l|}{ Model 1} \\
\hline$>6$ years & 1.62 & $1.02-2.55$ & 1.18 & $0.76-1.82$ \\
\hline$\leq 6$ years & 1.01 & $0.57-1.80$ & 0.63 & $0.33-1.18$ \\
\hline \multicolumn{5}{|l|}{ Model 2 (adjusted for age) ** } \\
\hline$>6$ years & 1.76 & $1.03-2.98$ & 1.17 & $0.75-1.84$ \\
\hline$\leq 6$ years & 1.64 & $0.88-3.04$ & 0.88 & $0.46-1.67$ \\
\hline \multicolumn{5}{|l|}{ Model 3 (adjusted for age ${ }^{\star \star}$, alcohol } \\
\hline \multicolumn{5}{|l|}{ consumption, smoking) } \\
\hline$>6$ years & 1.77 & $1.04-3.00$ & 1.22 & $0.78-1.93$ \\
\hline$\leq 6$ years & 1.63 & $0.87-3.05$ & 0.87 & $0.46-1.67$ \\
\hline
\end{tabular}

* For five subjects, data were missing on frequency of flossing.

** Age was analyzed as a continuous variable in all models.

*** To analyze experience of exposure and duration of exposure, dummy variables were created using "never exposed" as the referent category. Other variables were coded as: frequency of dental floss use $-0=$ frequent, $1=$ rare/never; alcohol consumption $-0=$ nondrinker, $1=$ drinker (occasional/frequent); smoking $-0=$ non-smoker, $1=$ smoker/ex-smoker.

ings were consistent with those of Tuominen 6, who observed that the association between exposure to inorganic acid vapors and periodontal pockets $\geq 4 \mathrm{~mm}$ occurred only in workers with more than 16 years of employment history.

It is well known that poor oral hygiene is a predictor of gingivitis but not of periodontitis, although there is a relative consensus that gingivitis need to be prevented to control periodontitis 12 . Oral hygiene status is directly related to the amount of dental plaque accumulated over the teeth and periodontal tissues 16, a precondition for the onset of periodontal disease 12 . In this study, the synergism between the use of dental floss and the association between acid mist exposure and PAL, besides demonstrating the relevance of oral hygiene for maintaining good periodontal health, also suggests that it can reduce the contact between periodontal structures and chemical agents that may enter the mouth. 
Strong inorganic acids such as sulfuric and chlorhydric acid, the principal components of acid mists, are irritant by their own and can affect the skin, eyes, and mucosa 21. Therefore, periodontal tissues may possibly be damaged by acid mists, which remain in the breathing zone 1 . Vianna et al. 1 observed that when lip sealing is absent, there is an increase in the association between occupational exposure to acid mists and ulcerative lesions of the oral mucosa. In this database the lip sealing covariate was not available for the analysis, and no evidence was found that oral breathing, a proxy of lip sealing, was an effect modifier of the main association.

The association between exposure to acid mists and periodontal disease may be a result of changes in intracellular and extracellular $\mathrm{pH}$, which plays an important role in the control of cell growth and differentiation. Changes in physiological pH determine genotoxic effects 5,19 which may be evidence of inorganic acid carcinogenicity. Chronic irritation of tissues by acids is also responsible for increased frequency of infections 5 , also found in association with salivary changes suchasthereductionofpH $\mathrm{H}^{20}$ and buffercapacity 21 , both related to periodontal disease. Exposure to sulfuric acid also leads to immune reactions such as a decrease in the phagocytic capacity of macrophages and cytotoxic activity of tumor necrosis factor, and increase the number of chromosomal abnormalities in human lymphocytes 5; it can also compromise the local immune response produced by the saliva, as well as the systemic response through immunoglobulin changes 21 . These mechanisms related to the individual defense system support our study findings.

It is now well known that PAL is the principal sign of destructive chronic periodontal disease, while gingival bleeding, periodontal pockets, redness, and suppuration are only acute reversible manifestations 14,15. Therefore, epidemiological studies have used PAL as the principal measure of the chronic irreversible stage of this disease 13,16,22. Conclusions from this study need to be interpreted with caution because of several methodological limitations. The study design is not the most appropriate for assessing causal association, because the antecedence of exposure to acid mists in relation to periodontal disease cannot be affirmed. Definition and classification of diagnosis and severity of periodontal disease pose difficulties for clinicians and researchers 13 , due to the multiple manifestations and complex etiology, where several risk factors have been described as playing distinct roles in the same individual and across different populations 23. Although clinical parameters from community periodontal index and attachment loss index 17 were used to assess periodontal disease in this study, each tooth was examined and all identified signs were recorded. The number of lost teeth was not considered in the analysis, thus leading to selection bias due to dental survival, i.e., towards the null hypothesis. This is plausible, since the prevalence of periodontal disease may be underestimated because only lesions in the remaining teeth were recorded 24 . Nevertheless, the observed positive associations support the conclusion that this bias was not sufficient to compromise statistical inference. Poor quality and missing information are common in secondary data like those used in this study and can lead to misclassification errors or selection bias. However this was not the case with this database, which is electronically managed and submitted to a rigorous quality monitoring and control. Exposure to acid mists was assessed using a semi-quantitative job exposure matrix, a method widely used in occupational epidemiology. Although the data are of limited quality as compared to quantitative data, the absence of more sensitive and specific instruments to provide more reliable data from industrial plants have made them a useful resource in workplace research 25

Thus, exposure to acid mists is a potential risk factor for periodontal disease, identified in this study by PAL, and further studies need to be done using a longitudinal design and more accurate exposure measures. It is also necessary to investigate the effects of the intensity of exposure to acid mists on periodontal structures. Our results show the importance of adequate oral hygiene for preserving periodontal health, even in the presence of chemical exposures such as those involving inorganic acids. However, since acid mists are also known to cause more severe health effects such as laryngeal cancer and neoplasm of the upper respiratory tract 5,19, workers' protection against these exposures are strongly recommended. In industrialized countries, acid mists have been subject to control for decades, and surprisingly, studies on their health effects have become rare. In developing countries, where acid mists are a common source of occupational exposure, health programs should emphasize oral hygiene because of its proven protective effect against several oral diseases, but health professionals should be aware that acid mist control programs are the most appropriate intervention for workers' protection. 


\section{Resumo}

Este estudo investigou a hipótese de que a exposição ocupacional a névoas ácidas está associada positivamente à doença periodontal, avaliada através da perda de inserção periodontal. O estudo foi conduzido com 530 trabalhadores do sexo masculino de uma metalúrgica. Os dados foram obtidos por meio de entrevistas individuais e de exames clínicos odontológicos. A perda de inserção periodontal foi avaliada durante a sondagem e definida em $\geq 4 \mathrm{~mm}$, em pelo menos um dente. Uma matriz de exposição ocupacional foi utilizada para avaliação da exposição. A exposição a névoas ácidas foi associada positivamente à perda de inserção periodontal $\geq 4 \mathrm{~mm}$ para a ocorrência da exposição em algum momento ( $\left.R P_{\text {ajustada }}=2,17\right)$, exposi ção passada $\left(R P_{\text {ajustada }}=2,11\right)$ e duração da exposição maior que seis anos $\left(R P_{\text {ajustada }}=1,77\right)$, independentemente da idade, consumo de álcool e tabagismo; estes resultados foram observados apenas entre os trabalhadores que não usavam o fio dental. A exposição a névoas ácidas é um fator de risco potencial para a perda de inserção periodontal e são necessários outros estudos que utilizem desenhos longitudinais e medidas de exposição mais acuradas.

Perda da Inserção Periodontal; Ácidos Inorgânicos; Doenças Periodontais; Exposição Ocupacional

\section{References}

1. Vianna MIP, Santana VS, Loomis D. Occupational exposures to acid mists and gases and ulcerative lesions of the oral mucosa. Am J Ind Med 2004; 45:238-45.

2. Mazzilli LEN. Odontologia do trabalho. São Paulo: Editora Santos; 2003.

3. Chikte UME, Josie-Perez AM, Cohen TL. A rapid epidemiological assessment dental erosion to assist in settling an industrial dispute. J Dent Assoc S Afr 1998; 53:7-12.

4. Tuominen ML, Tuominen RJ, Fubusa S, Mgalula N Tooth surface loss and exposure to organic and inorganic acid fumes in workplace air. Community Dent Oral Epidemiol 1991; 19:217-20.

\section{Contributors}

T. F. Almeida, M. I. P. Vianna, and V. S. Santana participated in the epidemiological analysis. T. F. Almeida, M. I. P. Vianna, V. S. Santana, and I. S. Gomes Filho participated in the theoretical review and drafting of the article.

\section{Acknowledgements}

Research funding was provided partially by the Ministério da Ciência e Tecnologia/Conselho Nacional de Desenvolvimento Científico e Tecnológico [CNPq; Brazilian Ministry of Science and Technology/National Research Council, Brazil, grant 522.621-96-1, and the National Institutes of Health NIHS/Fogarty Foundation/University of North Carolina at Chapel Hill, USA (grant. No. 1 D43 TW00827-01). The authors are also grateful to the Serviço Social da Indústria [SESI; Social Service for Industry], Brazil, which provided the staff support that made this study possible.
5. Agency for Toxic Substances and Disease Registry. Toxicological profile for sulphur trioxide and sulfuric acid. Atlanta: Agency for Toxic Substances and Disease Registry; 1998.

6. Tuominen ML. Occurrence of periodontal pockets and oral soft tissue lesions in relation to sulfuric acid fumes in the working environment. Acta Odontol Scand 1991; 49:261-6.

7. Lie T, Due NA, Abrahansen B, Boe OE. Periodontal health in a group of industrial employees. Community Dent Oral Epidemiol 1988; 16:42-6.

8. Amin WA, Al-Omoush SA, Hattab FN. Oral health status of workers exposed to acid fumes in phosphate and battery industries in Jordan. Int Dent J 2001; 51:169-74. 
9. Araújo ME. Estudo da prevalência das manifestações bucais decorrentes de agentes químicos no processo de galvanoplastia: sua importância para a área de saúde bucal do trabalhador. São Paulo: Universidade de São Paulo; 1998.

10. Vianna MI, Santana VS, McKelvey W. Periodontal health and oral mucosal lesions as related to occupational exposure to acid mists. Community Dent Oral Epidemiol 2005; 33:341-8.

11. Susin C, Vecchia CFD, Oppermann RV, Haugejorden O, Albandar JM. Periodontal attachment loss in an urban population of Brazilian adults: effect of demographic, behavioral, and environmental risk indicators. J Periodontol 2004; 75:1033-41.

12. Kinane DF. Causation and pathogenesis of periodontal disease. Periodontol 2000 2001; 125:8-20.

13. Kingman A, Albandar JA. Methodological aspects of epidemiological studies of periodontal disease. Periodontol 2000 2002; 29:11-30.

14. Haffajee AD, Socransky SS, Lindhe J, Kent RL, Okamoto H, Yoneyama T. Clinical risk indicators for periodontal attachment loss. J Clin Periodontol 1991; 18:117-25

15. Grbic JT, Lamster IB, Celenti RS, Fine JB. Risk indicators for future clinical attachment loss in adult periodontitis: patient variables. J Periodontol 1991; 62:323-9.

16. Albandar JM. Global risk factors and risk indicators for periodontal disease. Periodontol 2000 2002; 29:177-06.

17. Organização Mundial da Saúde. Levantamento epidemiológico básico de saúde bucal: manual de instruções. São Paulo: Editora Santos; 1999.

18. Oliveira NF, Santana VS, Lopes A. Razões de proporções e intervalos de confiança em regressão logística através do método delta. Rev Saúde Pública 1997; 31:90-9.
19. International Agency for Research on Cancer. Occupational exposure to mists and vapours from strong inorganic acids and other industrial chemicals. Lyon: International Agency for Research on Cancer/World Health Organization; 1992. (IARC Monographs, 54).

20. Hays GL, Bullock Q, Lazzari EP, Puente ES. Salivary $\mathrm{pH}$ while dissolving vitamin C-containing tablets. Am J Dent 1992; 5:269-71.

21. Silva CAL. Exposições ocupacionais a névoas ácidas e alterações salivares. Salvador: Instituto de Saúde Coletiva, Universidade Federal da Bahia; 2002.

22. Souza SLS, Taba Jr. M. Cross-sectional evaluation of clinical parameters to select high prevalence populations for periodontal disease: the site comparative severity methodology. Braz Dent J 2004; 15:46-53.

23. Kinane DF, Lindhe J. Patogênese da periodontite. In: Lindhe J, organizador. Tratado de periodontologia clínica e implantodontia oral. $3 a$ Ed. Rio de Janeiro: Editora Guanabara Koogan; 1999. p. 12752.

24. Papapanou PN, Lindhe J. Epidemiologia da doença periodontal. In: Lindhe J, organizador. Tratado de periodontologia clínica e implantodontia oral. 3 a Ed. Rio de Janeiro: Editora Guanabara Koogan; 1999. p. 43-65.

25. Boleij JSM, Buringh E, Heederik D, Kromhout H. Exposure assessment and evaluation in occupational epidemiology. In: Boleij JSM, Buringh E, Heederik D, Kromhout H, editors. Occupational hygiene of chemical and biological agents. Amsterdam: Elsevier Science BV; 1999. p. 161-206.

Submitted on $12 / \mathrm{Feb} / 2007$

Approved on 16/May/2007 